color. On dilution and standing several hours the solution became pale lavender, while a dark olivegreen semi-solid floated on top. This sample of unsaponifiable matter began to sof ten at about $75^{\circ} \mathrm{C}$., but was not sufficiently liquid to flow at $125^{\circ} \mathrm{C}$. It contained considerable ash not readily soluble in water, but soluble in dilute acid. The ash was found to contain some lime.

The low saponification value obtained by us was probably not due to insufficient saponification, as the wax was digested for five hours in very strong solution of caustic soda prepared by dissolving sodium in alcohol admixed with an equal volume of purified gasoline.

The wax acids separated from the soaps obtained in the saponification were dark brown, softer than the original wax and free from ash.

The wax was prepared ash-free by dissolving in boiling glacial acetic acid and pouring the hot filtered solution into an equal volume of cold dilute hydrochloric acid. After thoroughly washing the wax obtained in this manner with water, some of its chemical constants were determined and are given in the table with those of the wax as examined in the original state. The cause for the differences there shown is not apparent.

The dried and filtered commercial wax yielded on combustion the following average of two closely agreeing determinations:

Carbon, per cent .................. 80.30

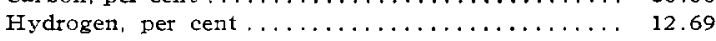

A sample of sugar cane wax analyzed by Dumas ${ }^{1}$ was found by him to contain $8 \mathrm{I}$ per cent. carbon and I4.16 per cent. hydrogen. He regarded this substance as an alcohol of the formula $\mathrm{C}_{24} \mathrm{H}_{50} \mathrm{O}$.

It will be observed that the candelilla wax is somewhat similar to the cane wax in its ultimate composition. The probabilities are, however, that candelilla wax like carnauba wax is a mixture of an alcohol, an ester, and some free fatty acid. If, however, an alcohol is present it should be possible to acetylate the unsaponifiable matter. We attempted the acetylation by the Benedict-Lewkowitsch method, but obtained negative results.

\section{CONSTANTS OF CHINESE WOOD OIL.}

$$
\begin{aligned}
& \text { By ADOLPH KREIKENBAUM. } \\
& \text { Received March 11, } 1910 .
\end{aligned}
$$

Chinese wood oil is a comparatively new article in general commercial use. It is now very much used in the manufacture of varnishes.

In the following work only the results of the determinations of the constants are given and a discussion of the analytical features added. The literature offers comparatively little definite regarding the constants of the oil and at most a considerable con-

\footnotetext{
1 Quoted by Browne in Bull. 91, Louisiana Experiment Station.
}

fusion of figures together with a wide range given for the various constants. ${ }^{1}$ In some cases in dividual analyses upon some sample of unknown or doubtful source is submitted and in other cases it is evident that a confusion of products is at fault in that Japanese wood oil and Chinese wood oil have been classed alike, ${ }^{2}$ being in the opinion of the writer two separate and distinct products. This opinion is based upon references found in literature $^{3}$ and not from original knowledge. The values given by Lewkowitsch in the table of constants for Chinese wood oil are evidently some Chinese wood oil and some Japanese wood oil figures. The values given for the specific gravity of Chinese wood oil by Lewkowitsch himself agree with the results obtained in this work. It seems that a distinction should be observed between the two products, Chinese wood oil and Japanese wood oil by all chemists, because the two oils are evidently separate and distinct substances, and the indiscriminate interchange of the figures of the two oils under one synonym Tung oil causes an unnecessary confusion and hardship for the analytical chemist, who may be compelled to make use of published data for reference.

The value of the work embodied in this article and the results obtained and submitted in their entirety are due to the fact, that the determinations of the constants have been made upon exact and carefully taken average samples of large commercial shipments of Chinese wood oil. This has been done for two years and the samples examined thus show how uniform a product the Chinese wood oil of commerce is. The investigation also reveals the fact that each constant varies but very slightly with the exception of the free acid value. The complete figures for each sample will tell their own story best.

All of the following specimens of the oil represent an average of regular commercial shipments. Several fluid ounces of the oil were taken from each barrel, emptied into a single container, mixed thoroughly and preserved in a tightly stoppered bottle filled close up to the cork and the bottles preserved in a dark, cool cupboard near the floor. More sperific details are given directly under the various specimens. The column marked $A g e$ in the analysis tables indicates the time alapsed between the receipt of the shipment and the date the particular analysis was made.

\section{Number $I$}

Shipment received October, 1907. Represents average of about Ioo barrels which bore the same brand. Filled one-gallon can full, tightly stoppered; kept in cool place. October, I 908 , transferred some of this

1 Toch, Chemistry and Technology of Mixed Paints, ed. 1907, p. 99; Chem, Engr., 9, 186

${ }^{2}$ Analyst, 23, 113, 118 .

3 Ibid., 23, 113,118; Kametaka, J.S. C. I., 27, abstract of J. Coll. Science Imp. Univ. Tokyo, 1908, p. 25; Lewkowitsch, Chem. Tech. and Anal. Oils, Fats and Waxes. 
oil into a I6-oz. bottle and filled nearly to the cork. Determinations made from this bottle sample:

\begin{tabular}{|c|c|c|c|c|c|c|c|c|c|}
\hline \multicolumn{2}{|c|}{ Spec. grav. } & 0.9416 & $\frac{15.5}{15.5}$ & \multicolumn{3}{|c|}{ Pycnometer. } & \multicolumn{2}{|c|}{$\begin{array}{l}\text { Age } \\
13 \text { mos. }\end{array}$} & Remarks. \\
\hline$"$ & $"$ & 0.9422 & $\frac{15.5}{15.5}$ & $"$ & & & & yrs. & $\begin{array}{l}\text { Poured from bot- } \\
\text { tle without shak- } \\
\text { ing. }\end{array}$ \\
\hline \multicolumn{4}{|c|}{ Free acid $4.8 \mathrm{mgs}$. $\mathrm{KOH}$. } & & & & 13 & mos. & \\
\hline Sapor & 1. No. & $\left.\begin{array}{l}192.2 \\
191.5\end{array}\right\}$ & 191.8 & & & & & “ & \\
\hline Iodin & $e . . .$. & $\left.\begin{array}{l}172.4 \\
170.8\end{array}\right\}$ & 171.6 & Hüb1 & & hrs. & 13 & " & $\begin{array}{l}\text { Hübl solution } 6 \\
\text { days old. }\end{array}$ \\
\hline “ & $\cdots \cdots$ & $\left.\begin{array}{l}170.0 \\
171.8\end{array}\right\}$ & 170.9 & “ & 3 & $"$ & 13 & $"$ & $\begin{array}{l}\text { Hübl solution } 7 \\
\text { days old. }\end{array}$ \\
\hline “ & $\cdots \cdots$ & $\left.\begin{array}{l}168.9 \\
169.2\end{array}\right\}$ & 169.0 & “ & 18 & $"$ & 16 & $"$ & 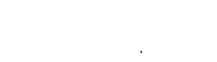 \\
\hline$"$ & $\cdots \ldots$ & $\left.\begin{array}{l}165.5 \\
164.5\end{array}\right\}$ & 165.0 & “ & 3 & $"$ & 16 & $"$ & \\
\hline “ & $\cdots \cdots$ & $\left.\begin{array}{l}170.0 \\
169.5\end{array}\right\}$ & 169.7 & “ & 4 & $"$ & 17 & “ & \\
\hline$"$ & $\cdots \cdots$ & $\left.\begin{array}{l}170.1 \\
170.2\end{array}\right\}$ & 170.1 & “ & 18 & " & 21 & $"$ & \\
\hline$"$ & $\cdots \cdots$ & $\left.\begin{array}{l}212.2 \\
209.4\end{array}\right\}$ & 210.8 & Hanus & 30 & $\min$. & 16 & $"$ & \\
\hline$"$ & $\cdots \cdots$ & $\left.\begin{array}{l}209.7 \\
206.6\end{array}\right\}$ & 208.1 & " & 30 . & “ & 16 & “ & \\
\hline$"$ & ..... & $\left.\begin{array}{l}208.3 \\
209.0\end{array}\right\}$ & 208.6 & “ & 30 & “ & 12. & $"$ & \\
\hline " & ...... & 196.0 & 196.0 & “ & 30 & " & 12 & $"$ & \\
\hline
\end{tabular}

Number 2.

Received October, I907. Average of Ioo barrels, the lightest colored ones found in a total lot of 600 barrels, coming from different shippers. One-gallon can full retained. Transferred some of the oil to bottle October, I908, from which determinations were made.

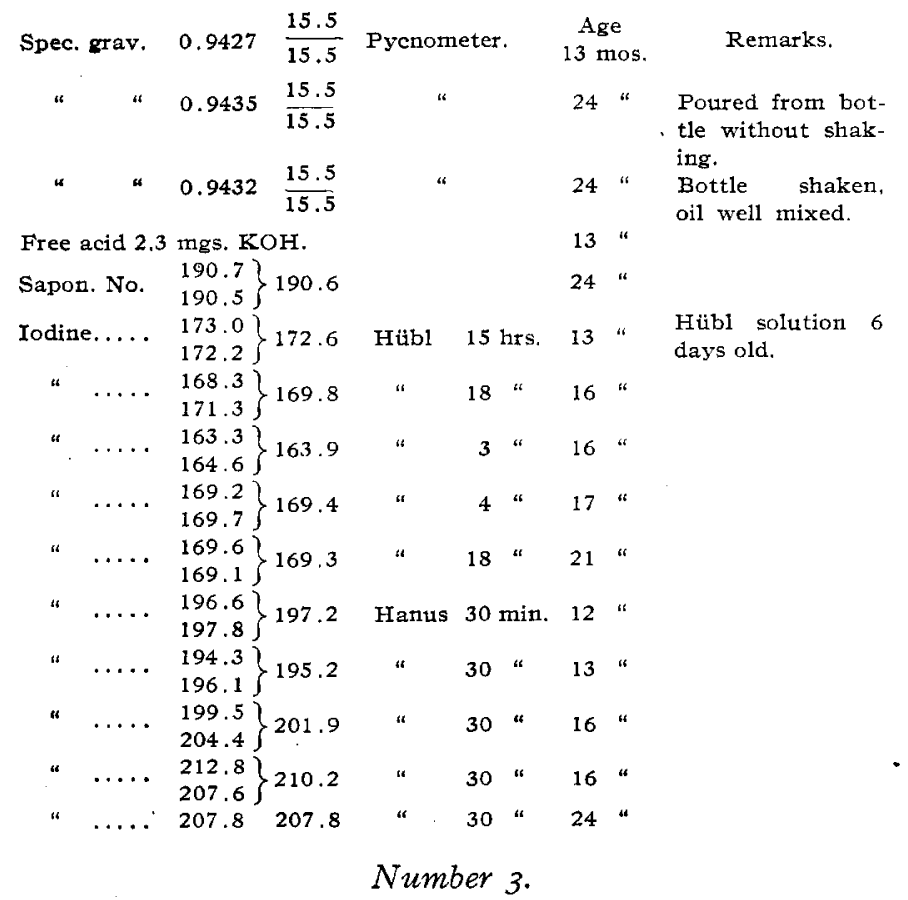

Received October, 1907. Average of 400 barrels darkest colored oil from a total of 600 barrels. Onegallon can of the oil retained. Transferred to bottle October, 1908 .

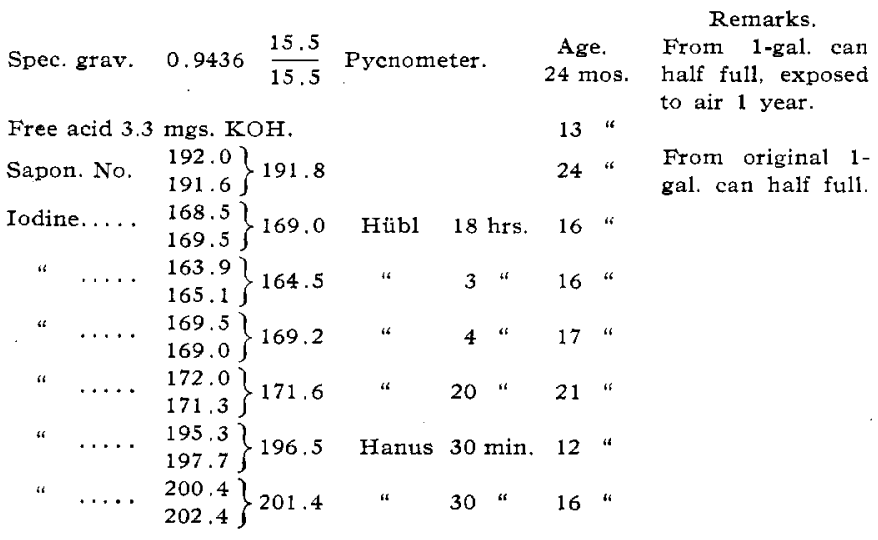

\section{Number 4 .}

Received October, I907. Average of 20 barrels marked with a certain brand. Light color. Sample kept in one-quart can in dark, cool cupboard near floor. Can about half-full. Transferred into bottle October, I908. Bottle completely filled.

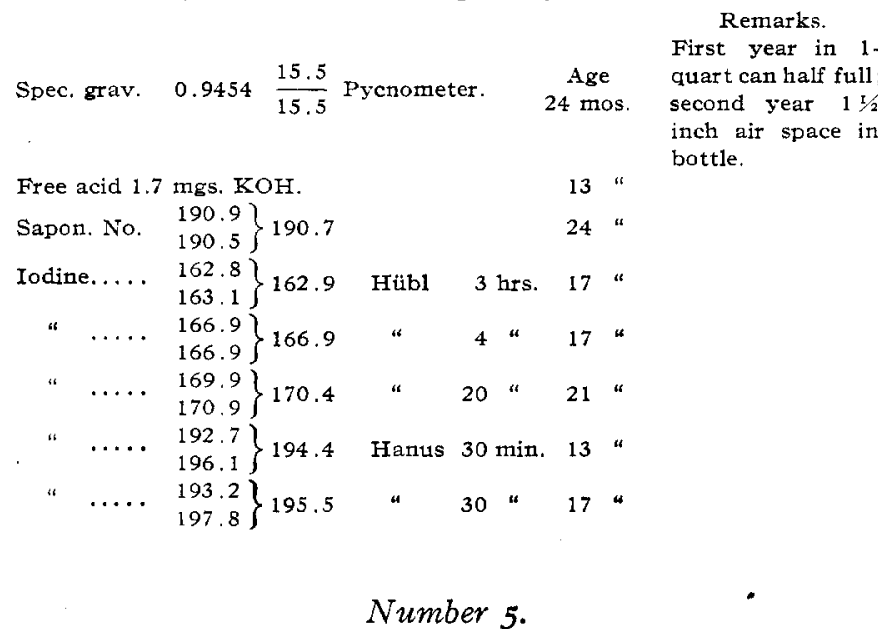

Received September, I908. Average of 88 barrels. Filled I6-oz. bottle and preserved like the rest in dark, cool cupboard.

\begin{tabular}{|c|c|c|c|c|c|c|}
\hline Spec. grav. & 0.9414 & $\frac{15.5}{15.5}$ & \multicolumn{2}{|c|}{ Pycnometer. } & & $\begin{array}{l}\text { Age } \\
\text { mos. }\end{array}$ \\
\hline Free acid 4.5 & fings. $\mathrm{K}$ & OH. & & & & days \\
\hline Sapon. No. & $\left.\begin{array}{l}191.2 \\
191.4\end{array}\right)$ & -191.3 & & & & mos. \\
\hline [odine..... & $\left.\begin{array}{l}165.3 \\
168.0\end{array}\right\}$ & 166.6 & Hübl. & 3 hrs. & & " \\
\hline$" \quad \ldots$. & $\left.\begin{array}{l}168.8 \\
169.5\end{array}\right\}$ & 169.1 & $"$ & $4 " 4$ & & “ \\
\hline “ & $\left.\begin{array}{l}173.7 \\
172.0\end{array}\right]$ & 172,8 & " & $20 "$ & 10 & " \\
\hline " & $\begin{array}{l}196.1 \\
195.9\end{array}$ & 196.0 & Hanus & 30 min. & 1 & “ \\
\hline$" \quad \ldots$. & 197.3 & 197.3 & " & $30 "$ & 5 & " \\
\hline “ $\quad \ldots$. & $\begin{array}{l}191.2 \\
204.1\end{array}$ & 197.6 & “ & $30 "$ & & “ \\
\hline
\end{tabular}

Number 6.

Received October, I908. Average of 400 barrels. Filled some in to bottle at once and preserved as usual. 


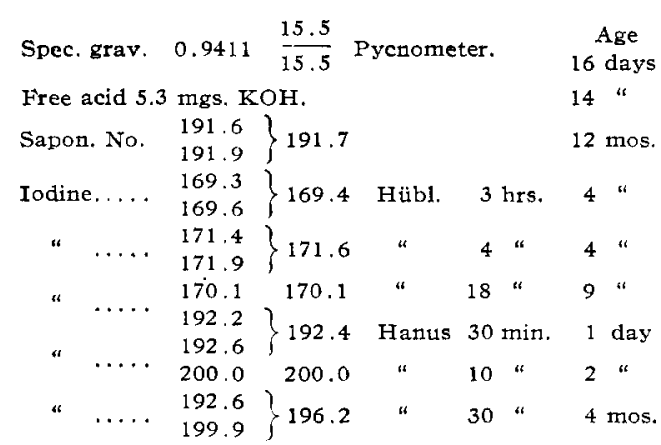

Number 7 .

Received October, 1908. Average of 100 barrels. Light color. Bottle sample preserved at once.

\begin{tabular}{|c|c|c|c|c|c|c|c|}
\hline \multicolumn{2}{|c|}{ Spec. grav. } & 0.9406 & \multicolumn{3}{|l|}{$\frac{15.5}{15.5}$} & $\begin{array}{l}\text { Age. } \\
2 \text { days. }\end{array}$ & \multirow{3}{*}{$\begin{array}{l}\text { Remarks. } \\
\text { From bottle. } \\
\text { From } 1 / 2 \text { gal. can } \\
\text { of same lot. } \\
\text { From bottle. }\end{array}$} \\
\hline$"$ & $"$ & 0.9401 & & & & 7 days & \\
\hline “ & “ & 0.9407 & & & & $12 \mathrm{mos}$. & \\
\hline & Free & cid $6.1 \mathrm{~m}$ & gs, KOF & & & 2 days & \\
\hline & & 6.3 & “ & & & & \\
\hline Sapon. & No. & 190.5 & 190.6 & & & 12 mos. & \\
\hline & & 190.7 & & & & & \\
\hline Iodine. & ..... & $\begin{array}{l}168.7 \\
170.2\end{array}$ & 169.4 & Hüb1. & 3 hrs. & 4 mos. & \\
\hline " & $\ldots$. & $\begin{array}{l}173.4 \\
173.3\end{array}$ & 173.3 & " & $4 "$ & $5 "$ & \\
\hline$"$ & & 170.3 & 1701 & $"$ & & 9 " & \\
\hline & $\cdots \cdots$ & 170.0 & 170.1 & & & 9 & \\
\hline$"$ & $\cdots \cdots$ & $\begin{array}{l}205.3 \\
205.9\end{array}$ & 205.6 & Hanus & $30 \mathrm{~min}$. & 2 days & \\
\hline$"$ & $\cdots \cdots$ & $\begin{array}{l}204.5 \\
208.1\end{array}$ & 206.3 & " & $30 "$ & $2 "$ & \\
\hline 4 & $\ldots$. & $\begin{array}{l}201.3 \\
191.0\end{array}$ & 196.1 & $"$ & “ & 4 mos. & \\
\hline$"$ & $\cdots$ & $\begin{array}{l}188.8 \\
189.0\end{array}$ & 188.9 & $"$ & $30 "$ & $5 "$ & \\
\hline "“ & $\ldots$ & $\begin{array}{l}201.0 \\
197.2\end{array}$ & 199.1 & “ & " & ." & $\begin{array}{l}\text { Bromine in excess. } \\
\text { Linseed, } 187.1 .\end{array}$ \\
\hline
\end{tabular}

Number 8.

Received June, I909. Average of 249 barrels. Oil stood in one-gallon can open to air for two weeks before bottle sample was transferred.

\begin{tabular}{|c|c|c|c|c|c|c|}
\hline Spec. grav. & 0.9413 & $\frac{15.5}{15.5}$ & & & & $\begin{array}{l}\text { ge. } \\
\text { mos. }\end{array}$ \\
\hline \multicolumn{5}{|c|}{ Free acid 7.0 mgs. KOH. } & 2 & \\
\hline Sapon. No. & $\begin{array}{l}190.0 \\
189.7\end{array}$ & 189.8 & & & 4 & " \\
\hline Iodine..... & $\begin{array}{l}170.7 \\
170.4\end{array}$ & 170.7 & Hübl. & $20 \mathrm{hts}$. & 1 & " \\
\hline
\end{tabular}

Number 9.

Received June, Igog. Average of 200 barrels. Oil left in open pail nine days before bottle sample was transferred.

\begin{tabular}{|c|c|c|c|c|c|c|}
\hline Spec. grav. & 0.9413 & $\frac{15.5}{15.5}$ & & & & $\begin{array}{l}\text { ge. } \\
\text { mos. }\end{array}$ \\
\hline Free acid 7 & Ings. $\mathrm{K}$ & $\mathrm{H}$. & & & & $"$ \\
\hline Sapon. No. & $\begin{array}{l}190.6 \\
190.5\end{array}$ & 190.5 & & & 3 & " \\
\hline $\begin{array}{c}\text { Iodine..... } \\
\text { “ } . . . .\end{array}$ & $\begin{array}{l}171.8 \\
171.5 \\
173.1\end{array}$ & $\begin{array}{l}171.6 \\
173.1\end{array}$ & $\begin{array}{l}\text { Hubl. } \\
\text { " }\end{array}$ & $\begin{array}{c}18 \mathrm{hrs} . \\
5 \approx\end{array}$ & $\begin{array}{l}1 \\
3\end{array}$ & " \\
\hline
\end{tabular}

Received September, I909. Average of 500 barrels. Filled in to bottle at once.

\begin{tabular}{|c|c|c|c|c|c|}
\hline Spec. grav. & 0.9412 & $\frac{15.5}{15.5}$ & & & $\begin{array}{l}\text { Age. } \\
\text { 1/2 mo. }\end{array}$ \\
\hline \multicolumn{6}{|c|}{ Free acid 2.4 mgs. $\mathrm{KOH}$. } \\
\hline Sapon. No. & $\begin{array}{l}190.8 \\
190.4\end{array}$ & 190.6 & & & $1 / 2 "$ \\
\hline odine.... . & 171.6 & 171.6 & Hübl. & $7 \mathrm{hrs}$. & $T / 2 "$ \\
\hline$" \quad \ldots \ldots$ & 167.9 & 167.9 & $"$ & & $5 / 2 "$ \\
\hline . . & 168.6 & 168.6 & " & $4 " \prime$ & $1 / 2 \quad "$ \\
\hline
\end{tabular}

The results of this work indicate quite conclusively that the Chinese wood oil of commerce is a very uniform product. The constants vary but little. Summarizing the results there are obtained the following figures for the constants:

Specific gravity $\frac{15.5}{15.5}$ by pycnometer 0.941
Free acid $\quad 1.7-7.1$ average $4.4 \mathrm{mgs}$. KOH
Sapon. No.
Iodine No. Hübl average 190.9
average $170.4 \%$.

The specific gravity of the fresh oil as received is practically $0.94 \mathrm{I}$. The minimum observation was 0.940 . In contact with air the specific gravity of the oil increases. Sample 4, which was in contact with much air for 2 years, gave at the end of that period 0.9454 and is the maximum figure obtained; others increased in a less degree. All determinations were made with the pycnometer. The Westphal balance, which gives accurate results upon such liquids as turpentine, benzine, alcohol etc., gives results I to 2 points in the third decimal too low when used for linseed oil or Chinese wood oil.

The free acid varied from a minimum observation of $\mathrm{I} .7$ to a maximum of $7.1 \mathrm{mgs}$. $\mathrm{KOH}$, with an average of 4.4 for the ten samples.

The saponification number is 190.9 , being the average of ten figures, minimum observation $\mathrm{x} 89.8$, maximum I 91.8 .

The iodine number proved to give interesting results, in the first place by giving such uniform results with the Hübl method and giving figures differing from those usually assigned to the oil in literature, and secondly, because the Hanus method was found inapplicable to Chinese wood oil. As a rule, the working of each iodine solution used, whether Hübl or Hanus, was tried for its action and result upon a sample of acid-free linseed oil kept for that purpose. The usual iodine number obtained for the linseed oil sample was $I 83^{-I} 84$ and the Chinese wood oil results were between $169-17$ I for these solutions. When the result on the linseed oil reached 185 , the Chinese wood oil (see sample 7) showed 173 . The Hübl solutions were from I 2 to 48 hours old when used, except in the cases where stated otherwise. It can safely be said that the iodine number by the Hübl method is quite uniform in the neighborhood of 170 and age has had practically no effect on it. A three-hour absorption is insufficient, a four-hour absorption giving in most cases almost complete results, assuming 18 hours as standard. For the 18 -hour absorption the minimum was I69.0, maximum I73.I. 
The average of all Hübl iodine absorptions between 4 and 20 hours is 170.4 . The 3 -hour absorptions gave an average of 166.9 on 8 determinations, with a minimum of 162.9 and a maximum of 170.9 . The 4-hour absorption shows an average of 169.7 on 8 determinations with a minimum of 168.6 and a maximum of 173.3 . Two 5 -hour absorptions gave 170.4 and I73.r. One 7-hour absorption gave I71.6. It can be assumed from the results of this work and upon the strength of it recommended that a 6- to 7hour absorption will in all cases give a complete iodine absorption by the Hübl method. The results show that no further remark is necessary than that the Hanus method is not available for Chinese wood oil, although each Hanus solution gave results with the linseed oil sample, which agreed closely with Hüb1 determinations upon the same, this being a check test nearly always made to prove that the Hanus solution was not at fault.

It is my sincere hope to see a complete research made upon Chinese wood oil, so that the figures, which I submit here, will be verified and that all might be known, which good investigation will bring out, and that we become more enlightened about this most curious of vegetable oils. Further work in confirmation and extension of these results will be taken up by coöperation with other investigators.

Chemical laboratory,

THE GLIDDEN VARNish Co.,

Cleveland, O., February 16, 1910.

\section{GAMBOGE.}

By F. O. TAYLOR.

Received March 10, 1910.

Of all the resins more commonly used there is none whose ordinary adulterations are more easy to detect than those of gamboge; nevertheless, we find that not only in the powdered state but also in the form of pipes or lumps it is largely adulterated. The adulteration of powdered resins is to be expected, but when the detection of adulteration is so simple a matter as with gamboge, one would imagine that at least more obscure methods of adulteration would be pursued. Such, however, seems not to be the case. For the purposes of this examination, fifteen samples of gamboge were obtained from a variety of sources, eight of these were powdered and seven were either pipes or broken lumps. The appearance of the powdered samples varied from an orange color to lemonyellow, while of the seven unpowdered samples, five were of first-class appearance and two were considerably lighter in color than a good quality of gamboge should be, one of these being in form of pipe and marked "Saigon Gamboge." The examination of gamboge for adulterations as published in pharmaceutical literature has been chiefly confined to the examination for starch and almost exclusively to the powdered form. Eberhard $t^{1}$ records his results in the examination of a number of samples of gamboge for starch and states that in several years' experience he had failed to discover a powdered gum that would not show at least a slight test for starch; in none of the samples of pipe gamboge did he discover any traces of starch. However, Daniel Base, in a paper before the Maryland Pharmaceutical Association, ${ }^{2}$ states that he found, by means of a microscopical examination, a number of samples of gamboge adulterated in this manner, but attributes some of the adulteration to the use of dextrin instead of starch.

The present examination included the percentage of ash, alcohol-soluble matter, acid value and test for starch, the results of which will be found recorded in the table following:

\begin{tabular}{|c|c|c|c|c|}
\hline $\begin{array}{l}\text { Sample } \\
\text { Numbe }\end{array}$ & $\begin{array}{ll}\text { e Starch } & \text { Test. } \\
\text { er. }\end{array}$ & $\begin{array}{c}\text { Per cent. } \\
\text { ash. }\end{array}$ & $\begin{array}{l}\text { Per cent. } \\
\text { alcohol, } \\
\text { soluble. }\end{array}$ & $\begin{array}{l}\text { Acid } \\
\text { value. }\end{array}$ \\
\hline 1 & Trace $($ under $1 \%) \ldots \ldots \ldots \ldots$ & 1.0 & 79.05 & 91.6 \\
\hline 2 & Marked.................... & 6.93 & 61.3 & 67.7 \\
\hline 3 & None $\ldots \ldots \ldots \ldots \ldots \ldots \ldots \ldots$ & 0.65 & 76.15 & 80.2 \\
\hline 4 & Very marked $\ldots \ldots \ldots \ldots$ & 11.00 & 39.25 & 56.3 \\
\hline 5 & Trace (faint). & 0.69 & 77.0 & 85.8 \\
\hline 6 & Heavy .................... & 1.91 & 57.6 & 67.7 \\
\hline 7 & Very marked $\ldots \ldots \ldots \ldots \ldots \ldots \ldots$ & 6.76 & 61.0 & 73.3 \\
\hline 8 & Trace (under $1 \%$ ) $\ldots \ldots \ldots \ldots \ldots \ldots$ & 1.02 & 60.1 & 64.9 \\
\hline 9 & Very marked $\ldots \ldots \ldots \ldots \ldots \ldots \ldots$ & 0.93 & 52.95 & 80.5 \\
\hline 10 & None $\ldots \ldots \ldots \ldots \ldots \ldots \ldots \ldots \ldots$ & 0.45 & 84.0 & 95.8 \\
\hline 11 & None $\ldots \ldots \ldots \ldots \ldots \ldots \ldots \ldots$ & 0.54 & 77.4 & 85.8 \\
\hline 12 & None...................... & 0.32 & 82.0 & 88.6 \\
\hline 13 & 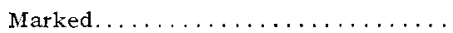 & 0.71 & 60.3 & 73.3 \\
\hline 14 & None $\ldots \ldots \ldots \ldots \ldots \ldots \ldots \ldots$ & 1.26 & 74.9 & 81.6 \\
\hline 15 & Heavy $\ldots \ldots \ldots \ldots \ldots \ldots \ldots \ldots$ & 0.70 & 49.95 & 64.9 \\
\hline
\end{tabular}

Starch Test.-The U. S. P., Eighth Revision, includes no test for the presence of starch in gamboge, differing in this particular from the U. S. P., I890. This was probably done with the supposition that gamboge in pipes, which is the only variety official, is not adulterated with starch. This is unfortunate, as out of seven samples of this character which were examined, two were markedly contaminated with starch, and in such a manner that it was evidently an intentional adulteration. The test given in the U. S. P., I89o, is sufficiently delicate for all practical purposes and is easily applied. Eberhardt (v. s.), while admitting the delicacy of this test, has proposed another based on the destruction of the starch granule with caustic alkali (which at the same time dissolves the gamboge resin), the precipitation of the resin and neutralization of the liquid with acid, and the testing of the filtrate with iodine. This test has the advantage of giving the blue color of starch iodide instead of the green color which appears when this blue is mingled with the yellow of the gamboge. In every case I have used the former U. S. P. test, which will, without difficulty, detect much less than one per cent. of starch.

Not one of the powdered samples showed but a trace of starch. In number 5 this was faint, in num-

\footnotetext{
1 Amer. Jour. Pharm., 1896, p. 371
}

2 Ibid., 1900, p. 189. 